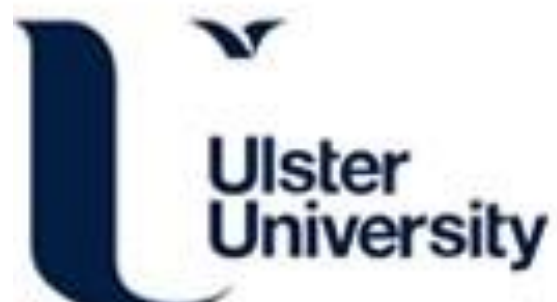

\section{A Qualitative Study of the Perspectives of Domestic Violence Survivors on Behavior Change Programs With Perpetrators}

McGinn, T., Taylor, B., \& McColgan, M. (2021). A Qualitative Study of the Perspectives of Domestic Violence Survivors on Behavior Change Programs With Perpetrators. Journal of Interpersonal Violence, 36(17-18), NP9364-NP9390. https://doi.org/10.1177/0886260519855663

Link to publication record in Ulster University Research Portal

Published in:

Journal of Interpersonal Violence

Publication Status:

Published (in print/issue): 01/09/2021

DOI:

10.1177/0886260519855663

Document Version

Author Accepted version

\section{General rights}

Copyright for the publications made accessible via Ulster University's Research Portal is retained by the author(s) and / or other copyright owners and it is a condition of accessing these publications that users recognise and abide by the legal requirements associated with these rights.

\section{Take down policy}

The Research Portal is Ulster University's institutional repository that provides access to Ulster's research outputs. Every effort has been made to ensure that content in the Research Portal does not infringe any person's rights, or applicable UK laws. If you discover content in the Research Portal that you believe breaches copyright or violates any law, please contact pure-support@ulster.ac.uk. 


\title{
A qualitative study of the perspectives of domestic violence survivors on behaviour change programmes with perpetrators
}

Tony McGinn, Lecturer in Social Work

Brian Taylor, Professor of Social Work

Mary McColgan, Professor of Social Work

Ulster University, Northern Ireland

\section{CORRESPONDING AUTHOR: Tony McGinn t.mcginn@ulster.ac.uk}

CITE AS: McGinn T, Taylor BJ \& McColgan M (2019) A qualitative study of the perspectives of domestic violence survivors on behaviour change programmes with perpetrators. Journal of Interpersonal Violence, 36(17-18), NP9364-NP9390. https://doi.10.1177/0886260519855663 [published 19 June 2019; issue published 01 September 2021]

\begin{abstract}
This study investigated the process of change in Intimate Partner Violence (IPV) perpetrators through in-depth interviews with their (ex-)partners. Programmes designed to help perpetrators change their behaviour, have yet to be endorsed by rigorous evaluation. In this context, this study explored survivors' perspectives for direction on how these programmes might be further developed. Interviews were conducted with eighteen IPV survivors, who had recently had the experience of having a (ex-) partner complete a perpetrator programme.
\end{abstract}

The study employed iterative data collection and analysis, in keeping with the grounded theory approach to qualitative research. Researchers used secondary coding to enhance study rigour. Lines of enquiry which were relevant to perpetrator programme development where identified in an expert review of interim findings, after nine interviews.

Survivors described change on a spectrum, from highly significant change, through uncertainty about change, to harmful change. Some survivors described their subscription to new standards of family safety, following the support and time-out they had been afforded during their partners' treatment. Study findings give us pause to consider what we can realistically hope to achieve through traditionally formatted psycho-educative group-work programmes with perpetrators. Survivors described the need for long term sustained changed in perpetrators, and genuine feelings of safety for themselves, and their children.

The authors discuss the role current perpetrator programmes might play in achieving these aims and point toward the inadequacy of commonly used behaviour-counting tools in programme evaluations. Based on current study findings, the authors suggest that perpetrator programmes can become perpetrator-centric, and stray from their original conceptualisation as just one part of an integrated response to IPV. The authors lend support to calls for the use of survivor safety, and well-being measures, in programme evaluations. 


\section{Context}

It is difficult to see a trajectory of progress in how we work with IPV perpetrators. Manualised behaviour change programmes, delivered to groups of perpetrators, became popular in the early 1980s with the apparent success of the Duluth model of practice (Pence, 1983). The 90s cast a shadow over these interventions. A systematic review by Babcock, Green, and Robie (2004) which was ambivalent about their usefulness, attracted the attention of many in the field. A series of reviews and metaanalyses have been conducted since (Akoensi, Koehler, Lösel, \& Humphreys, 2012; Coulthard et al., 2010; Feder, Wilson, \& Austin, 2008; Ferrer-Perez \& Bosch-Fiol, 2016; Smedslund, Dalsbø, Steiro, Winsvold, \& Clench-Aas, 2011). None of these have offered clear direction on the harm or benefits of any particular variation of the traditional manualised group work programme, despite the development of curriculums in line with ascendant therapeutic modes such as psycho-education (Rosenbaum, Gearan, \& Ondovic, 2001) cognitive behavioural therapy (Easton et al., 2007) and dialectical behaviour therapy (Fruzzetti \& Levensky, 2000).

Arguably, we are at something of an impasse regarding work with IPV perpetrators. Some commentators put a positive slant on programme evaluations to date (Bloomfield \& Dixon, 2015; Kelly \& Westmarland, 2015). However, endorsements from rigorous evaluations have not materialised. A notable exception was the large scale Brooklyn experiment (B. G. Taylor, Davis, \& Maxwell, 2001) which showed a significant positive effect, a result which was later discounted as a perpetrator monitoring effect rather than a perpetrator programme efficacy effect (Maxwell, Davis, \& Taylor, 2010). In the UK, the volume of perpetrators completing programmes is now quite low (Kelly and Westmarland) hampering efforts to evaluate with rigour. It could be suggested that the continued provision of perpetrator programmes, may be driven more by an unconscious policy edict that we must do something (Feder et al., 2008; Jennings, 1987) than reference to an evidence base which suggests the efficacy of intervention.

Against this background, a number of researchers have been chipping away at the unknowns in the field of IPV perpetrator intervention. We would suggest that a number of promising leads for perpetrator programme development have been unearthed through studies of interventions processes, and the barriers to and facilitators of change. Findings from these studies have been usefully brought together in a series of reviews. Correlates of perpetrator attrition from intervention, and methods of encouraging perpetrator motivation to change, have been reviewed by Saunders (2008) and Jewell and Wormith (2010). Research on perpetrators' readiness to change has been reviewed by Scott and King (2007). Research on perpetrator typologies and their utility for intervention programs are reviewed by Cavanaugh and Gelles (2005), Hamberger (2008), and Walker, Bowen, Brown, and Sleath (2015). Ecological factors which affect treatment, including couple dynamics, are reviewed by Stith, McCollum, Amanor-Boadu, and Smith (2012) and Stith et al. (2000). While Stover, Meadows, and Kaufman (2009) summarize studies which have helped us understand substance abuse as a barrier to change.

The dominant academic perspective of the 80 s and $90 \mathrm{~s}$, that violent men need to be held to account and taught new ways of behaving, has therefore been problematised. 
It has been over-taken by an interest in more specific treatment targets, mechanisms of change and sub-categories of perpetrator, including categories of perpetrator who are unlikely to change. Allied to this shift in perspective, on the nature of perpetrator change, is the beginnings of a shift in perspective on evaluating programmes. Pivotal evaluations of the 90s and 00s (R. P. Dobash, Dobash, Cavanagh, \& Lewis, 1999; Dunford, 2000; Feder \& Dugan, 2002) used the Conflict Tactics Scales (Straus, Hamby, Boney-McCoy, \& Sugarman, 1996) and similar questionnaires to quantify incidents of violent behaviour, using (ex-) partner reports. This approach is widely acknowledged as a step up, in methodological rigour, from using perpetrators' reports of their violence as an outcome measure (Gondolf, 2012). However, more recently, there have been calls to further improve the validity of perpetrator programme evaluation measures. Westmarland and Kelly (2012) offer findings from a qualitative study of survivor perspectives in support of more holistic, family-centric measures. A view which has attracted some degree of endorsement (Alderson, Westmarland, \& Kelly, 2013; Clarke \& Wydall, 2013; Katz, 2016; Valentine \& Breckenridge, 2016).

Advocates of evaluation which goes beyond violent behaviour counting include Wojnicka, Scambor, and Kraus (2016) who have forwarded a European standard for perpetrator programme evaluation. Wojnicka et al., outline the need for outcome measures which capture data pertaining to: relationship dynamics and the quality of communication in relationships, or following relationships; how much space survivors are being afforded, to take action and make changes in their life; feelings of safety; and the general well-being of children and survivors. However, a number of recent programme evaluations (Bloomfield \& Dixon, 2015; Haggård, Freij, Danielsson, Wenander, \& Långström, 2015; Hasisi, Shoham, Weisburd, Haviv, \& Zelig, 2016; Zarling, Bannon, \& Berta, 2017) have offered reconviction data only to evaluate perpetrator programmes. Further emphasis, in the realms of practice, policy and research, is necessary to drive home the message: counting violent incidents, and measuring recidivism is not an adequate way to evaluate and inform the development of interventions for IPV perpetrators.

Current study findings add insights from survivors in Ireland, who have experienced their violent (ex-) partner's involvement in an IPV perpetrator programme. These survivors' perspectives are pertinent to the task of developing perpetrator programmes, in particular, these perspectives have implications for how we evaluate perpetrator programmes. A review of previous studies of survivor perspectives on perpetrator programmes (McGinn et al., 2015) found that survivors sometimes experienced changes in perpetrator behaviour, as a result of perpetrator programmes. Survivors have described how violent partners used conflict interruption techniques and new communication skills, which they learned about on behaviour change programmes, to good effect. However, McGinn et al. (2015) pointed out the distinction between these behavioural changes and more in-depth change such as change in perpetrators' belief systems, and the adoption of new perspectives. They also summarise insights, from previous studies, into potential problems with perpetrator programmes. Such as, additional stress experienced within perpetrators' families when perpetrators are forced to attend a programme; or the learning of new skills which perpetrators use to further exercise control; or the obligation placed upon survivors to stay in a relationship while their partner attempts to change. 
Using findings from McGinn et al. (2015) as a conceptual framework, attuned to both positive and negative effects of IPV perpetrator programmes, this study explores Irish survivors' perspectives. It is important to continue to explore survivors' perspectives on perpetrator programmes because survivors are first in the firing line when interventions fail to deliver. Survivors can offer first-hand accounts of what it is like to have a violent partner on one of these programmes, and their insights have been argued to be more objective than that of perpetrators (R. E. Dobash, Dobash, Cavanagh, \& Lewis, 2000; Gerlock, 2001; Silvergleid \& Mankowski, 2006). These are insights which can help modify the provision of perpetrator programmes for the better.

It should be noted that the authors acknowledge the importance of developing more effective responses to female perpetrated IPV, and male victims and survivors. These populations are not as large (Office for National Statistics, 2015) they are difficult to access, and were beyond the scope of the current study. It is hoped that current study findings have some relevance to the development of services for female perpetrators and male victims.

\section{Method}

The study drew upon grounded theory (Glaser \& Strauss, 1967). In keeping with this methodology we approached the process of data collection and analysis without having an a priori theoretical standpoint. The core topic areas were: experience of the programme; process of change; types of change; facilitators of change; barriers to change; and programme development. As prescribed by Glaser and Strauss we deployed an iterative approach to data collection and analysis. Each interview was transcribed after it was completed, and these data, the transcripts, were coded before moving on to the next interview. Open coding was applied to the first four interviews: labels which were quite close to the actual study participant utterances were applied. Open coding continued through to the tenth interview transcript, but was progressively overtaken by the construction of data categories, and selective coding. By constantly comparing our coding in subsequent transcripts, with coding in previous transcripts (axial coding; Glaser and Strauss) data categories were constructed, each with properties and dimensions. Where a data category was deemed to have implications for perpetrator programme design, and modification, subsequent interviews were used to explore the data category with study participants. The final six interviews were almost entirely focused on selected data categories, and transcripts from these interviews were coded using selective coding, that is, coding relating to selected categories of interest.

The target population for the study were survivors who experienced having a partner involved in a traditionally formatted perpetrator programme, in Ireland (Northern Ireland and the Republic of Ireland). The term 'traditionally formatted' is used here to describe programmes which are: predominantly delivered via group-work; progress through a pre-set curriculum over a set number of weeks; and which involve on-going contact with perpetrators' (ex-) partners, through an outreach-worker. We identified six perpetrator programmes, in the region, which offered traditionally formatted behaviour change programmes to perpetrators. Three of these agreed to take part: Western Health and Social Care Trust $(n=3)$, MOVE Ireland $(n=11)$ and the National Society for the Protection of Cruelty to Children $(n=4)$. These were not court-mandated 
programmes, however, many of the perpetrators were involved in child protection procedures.

Abuse survivors, who had had a (ex-) partner involved in a perpetrator programme were recruited to the study by their outreach worker, from the perpetrator programme. Participant recruitment began with perpetrator group facilitators and outreach workers completing a screening exercise. While abuse survivors have reported that participation in qualitative research, can be beneficial to survivors (Fontes, 2004; Griffin, Resick, Waldrop, \& Mechanic, 2003; Scerri, Abela, \& Vetere, 2012) the authors were also conscious of the particularly difficult circumstances some survivors are in. Survivors who were in imminently dangerous situations were not asked to take part, for example, if outreach workers thought they were at a very high risk of serious physical assault. Survivors who were currently struggling to meet their appointments with child protection services, court services or advocacy services were not asked to take part, to avoid placing them under additional pressure.

When a sampling frame of eligible study participants was established across the three agencies, the interviewer chose interviewees in keeping with the principle of theoretical sampling: "participants in different situations are chosen as they are needed to help the researcher clarify understanding" (McCallin, 2003, p. 204). The pursuit of information-rich data takes precedence in theoretical sampling. Interviewees were selected for the alternative perspectives they could offer, which varied between positive and negative experiences of intervention and behaviour change.

Interviews were conducted on service provider premises, by the first author. Interviews were recorded using a digital voice recorder and guided by an aide memoire. The aide memoire was modified during the course of the study, in keeping with the iterative nature of grounded theory research.

The study was preceded by two literature reviews, built on systematic bibliographic searches (McGinn et al., 2015; McGinn et al., 2020). These reviews described a lack of reported study rigour in previous research in this area. There is a recognised possibility of bias toward verification of theoretical positions, in a highly contested research topic area such as this; see Dutton and Corvo (2007) versus Gondolf (2007). For these reasons the current study employed mechanisms of study rigour as far as resources would allow, as follows.

- Previous qualitative studies of perpetrator and survivor perspectives, on perpetrator programmes, were systematically synthesised to provide a conceptual framework to guide data analysis.

- A study sample which was as widely representative as possible; drawn from three separate perpetrator programme providers geographically spread across the Island of Ireland.

- The depth of insight obtained during data collection was enhanced through prolonged engagement (interviews averaged 74 minutes in duration) Rubin (2000) suggests that prolonged engagement increases the depth of understanding obtained from qualitative research.

- Interviews one, two, four and eight were also coded by an independent coder, in keeping with the inter-coder reliability check described by B. J. Taylor and Donnelly (2006). Accepting some flexibility in word choice, for the descriptors applied to data 
categories, inter-coder agreement was $78 \%$. Minor adjustments were made to the main coder's choice of data categories as a result.

- An expert validation exercise was completed after eight interviews had been completed. Eight group work facilitators and outreach workers were consulted to ascertain which emergent data categories were most likely to lead to findings with a practical implication. This informed the direction of enquiry in subsequent interviews.

- Review findings were underpinned by an audit trail generated by the software application NVivo;

Ethical approval for the study was provided by the Office for Research Ethics Committees Northern Ireland.

\section{Findings}

The current study report presents survivors' experiences of change, following their violent (ex-) partners' completion of an IPV perpetrator programme. All 18 study participants were female. Their average age was 40.2 years. Participants had been in a violent relationship for an average of 12 years. Nine of the interviewees were separated from, and nine were still in a relationship with, a partner who had been on a perpetrator programme. In all cases there was still some level of contact between study participants and their violent (ex-) partner. The study participants' partners had completed a perpetrator programme, on average, within the previous 94 days. Three interviewees were unemployed at the time of the interview (several interviewees were looking after their children, full-time, they were therefore counted as employed).

It should be noted that, in the extracts from interviews which follow, pseudonyms are used and some minor details have been changed so that quoted material cannot be used to identify study participants.

\section{Empowerment}

It was clear that having one's (ex-) partner involved in a perpetrator programme affected study participants' sense of empowerment. For some survivors it was an empowering experience, for others, the opposite.

Seven study participants felt validated, as survivors, and empowered by the discussions which the programme had initiated with their (ex-) partner. Discussions such as that described by Bethany:

I think there was times where they had to pick particular things they had done, and go through it, verbalise and maybe go through piece by piece. And he felt that very uncomfortable, and I know he said to me that it was the fact that when he actually verbalised it, and said it to somebody else, and listening to it, he found it horrendous to think, that's what he did to me. (Bethany.)

Survivors clearly valued any insights, that they gleaned from these discussions, about how or why their partner was violent. Jackie came to the following understanding through discussion of programme work with her (ex-) partner, and with some input from her partner outreach worker:

I would never have called him a jealous person but apparently, he was, this was something we both learned together, he was pulling me down all the time apparently to keep me. And obviously, something we both learned was, he was pushing me away, what he was trying to do was the complete opposite 
because by being violent and being controlling and being all those things, he was keeping me, yes he was physically keeping me but he was pushing me away. He was losing me. (Jackie.)

In addition to survivors becoming validated as survivors, because their (-ex) partner was on a perpetrator programme, and because of the type of work he was completing on the programme, survivors also felt supported through partner outreach work. For many, this provided them with a new outlook. For example:

For me, purely on a personal level, to be able to talk to somebody and identify, and help me both learn about his behaviour, maybe why he was doing things or why things can happen, and then about obviously myself too, why things were maybe wrong. And ridiculous as it sounds, and that it was ok for me to stand up for myself. (Alice.)

I did learn an awful lot through (name of outreach worker) and through (agency name) about myself and about ... I know this is going to sound ludicrous, but sometimes when you're told something by somebody else, it almost validates it for you, I don't know if that sounds crazy, I'm a 49 year old woman, I'm not stupid, not the cleverest but l'm not stupid, but sometimes when somebody says it to you. (Geraldine.)

In some cases, this support, and increased insight appeared to have elevated survivors' ideas about what they wanted from their relationship. The following study participants saw the programme as providing their (ex-) partner with the tools to change, and part of a journey toward change, or separation.

He thinks that he is a bad person, and he won't delve deep enough into himself. That ... he takes it very personally, of course he takes it personally. But this is going to be a major loss to him this is going to affect him if he can't sort this out. (Audrey.)

There could have been a change in me as well, I have done so much counselling, I have learned to stand up for myself, and not to take any of the crap that he was giving me. And when we separated I realised that I could stand on my own two feet, successfully. (Denise.)

To be honest if there was (another incident) that would be it. That, ... I wouldn't care how much counselling was involved I wouldn't go through any of this again. This is his last warning if you like. Maybe he knows that. Maybe he senses that, and he sees this as his last chance. (Mary.)

In summary of these findings relating to survivor empowerment: having a violent partner on an IPV perpetrator programme can help validate survivors' position as survivors, they value the insights they obtain about their partners' behaviour. They are likely to feel supported through the partner outreach work which comes along with traditionally formatted perpetrator programmes, and some survivors re-assess their position, and options, during this time.

\section{Safety}

Survivors' realisations that their partner was unlikely to ever be the partner they wanted him to be, together with memories of past abuse, fed into varying levels of fear 
for the future. For example, the following study participant was among the most enthusiastic about the changes she perceived in her violent partner, but was still apprehensive:

I think there is still a level of fear. If you're to put it on a scale of 1 to 10 , I think I will always be around two, number two number three, ... you know when you've gone through years of that kind of behaviour, I find it very hard, the old expression 'a leopard never changes its spots'. Even though you want to give someone the benefit of the doubt, so much, that fear will always be there. (Lisa.)

A safe separation, free from fear of repercussion, was the change that seven of the eighteen study participants wanted. The following interviewee was in tears for much of the interview. She described how she desperately wanted to separate from her partner, but could not afford to. Her partner continued to live with her against her wishes. He had made it clear that he could not learn anything from a perpetrator programme, but had nonetheless completed a programme upon the recommendation of his solicitor:

We are separated but we are living in the same house for financial reasons I can't move out, he has also told me that if I try and take the kids (pause) he has said some really nasty things. (Jan.)

There was a sense of helplessness in the narratives provided by survivors such as Jan. It was clear that some interviewees were in very difficult situations. Discussions of concepts such as stages of change, or attitude change, concepts which perpetrator programmes are commonly built around, seemed redundant when survivors feared for their safety, and could not extract themselves from abusive relationships.

The only way I could get away from him, is if he found a different person, because he was like the exact same, in the relationship he had before me. And then he tortured her, until he found me, and then that was him moved on, so he would need to find somebody else. (Jill).

There were insights into interventions which did, and did not, help survivors when they wanted to separate. They described the no-contact orders variously, as helpful and not helpful, when they alone were left to enforce them. Three survivors had partners incarcerated, they cited this as a valued change in dynamic for them, and one described how a 'no-drop prosecution' policy helped. If a safe separation was the key outcome of interest for these survivors, we should consider if the resource applied to encouraging their violent (ex-) partner through a perpetrator programme could have been more appropriately applied to bringing a safe separation about, through a custodial sentence, or a properly enforced no-contact order.

The following interviewee was one of three, who described how the incarceration of their partner provided respite from fear, and a sense of safety, however temporary:

Interviewee: Yeah, because, him going to jail, you know he's out (of the house) he's away.

Interviewer: Was that the most important thing, in this whole thing, him going to jail?

Interviewee: Aye, definitely. To know, with my four children, we were just able to do one thing, relax, and be ourselves, and then. When he was back out, you would be all up tight. (Justine.) 


\section{Sustainable change}

The interviews provided survivors' perspectives on the sustainability of the changes, they had experienced, in their violent partner. There was evidence to support the idea, drawn from the literature reviews that there is a fundamental difference between changes in behaviour and changes in underlying beliefs, for example:

Interviewer: It sounds as if the programme has changed behaviour quite clearly. I wonder what the programme has done to your partner's underlying beliefs?

Interviewee: Well I'm just afraid that part is slowly going back to the way he was. Although his behaviour has improved, ... but little things, if he doesn't get those little things which I feel are very important, ... but at the same time he can stay very calm, ... He always said, that when he went to the programme he thought we would get back together, he said that some of the lads (on the programme) would say that they are working at it to see their children, that's it, he would say that he wanted his family back too so, if he feels that he is not going to get his family back, after trying all this, then maybe he will say "well what is the point, what's the point in behaving myself, what's the point?" Because at the end of the day, and thinking of (family occasion) and what he said at (family occasion) he said he was doing everything that everyone wants but he wasn't getting anything out of it. (Teresa.)

Several survivors felt unsure about the depth of change they were seeing in their (ex) partners. While survivors welcomed changes in perpetrators beliefs, which enabled perpetrators to verbalise that a particular behaviour is wrong, some survivors also wanted their (ex-) partner to feel that something is wrong, autonomously. They wanted perpetrators to be governed by emotions such as love, or respect for one's family, for example:

But I think with regards to the issues, and him looking at things, he looks deeper now generally at things you know, l'd like to say it has made enough of a difference, I don't think, I think a lot of it is still ... sometimes he is doing what we have told him to do. My problem is I don't think he necessarily feels those feelings, if that makes sense, he's told to do it, he's verbalising it, I personally feel he doesn't always feel as deep as he says he does, if that makes sense. (Jocelyn.)

It can be seen that 'changes in beliefs' may not fully describe the extent of change that some survivors needed. A fundamental 'change in character' may be a more appropriate conceptualisation.

\section{Children}

Most survivors who had children of a dependent age thought about the perpetrator programme in terms of what it had done for their children's welfare. Four survivors described how the programme had a clear benefit for their children, for example:

He used to ... he did not look at the children, he didn't know the children, he wouldn't spend time with the children, now he is very different, now he is doing. He came into the school! He is spending time with them, picking them up from the school, taking them to (sports) ... It has been almost a year now. It is not like, just because the social workers were out of our lives that he can stop being like this, he is coming up with new ideas every month. Things for us to 
do, things that we want to do, that the children want to do. So, it is not just a temporary thing. I am really happy with that course. I would say that I don't know how to thank them all. (Jane).

Others saw no change, that their children would benefit from, and spoke about ongoing difficulties relating to the safety and well-being of their children, for example:

Interviewee: He was very violent towards me, I suppose hitting out at me, and the children, I suppose it is more verbal now, like he would hit you, now if he could get away with it ... my oldest one is 17 now, it's kind of a tough age, they think they know it all, I suppose they are trying to find independence, but I find I have enough to deal with it, without dealing with his problems, you know, and if he was around her, the danger is he would hit her, you see he is just not able to deal with any pressure ...

Interviewer: And whenever he would upset one of the girls, would he be sorry about that?

Interviewee: I remember asking him, why did he do that, and he said 'Ah that bitch got what she deserves.'

\section{Detrimental changes}

Finally, some survivors offered insights into negative programme effects. Survivors provided insights into three problematic programme effects in particular. Peer support between partner violent men has been argued to have the potential to normalise their violence. The study provided a few examples of how interactions on the programme could be seized and processed in the wrong way, for example:

There were something in the programme that made him feel that he is a 'valued person', which they say in the programme. And even though you've behaved badly and you've done these things, you are still a valued person, which is good. But I have felt, personally, I don't know how much it's enforced, there was a twist in that ... He uses it in the other way, like I am a valued person, how dare you tell me l'm wrong. This has come up only recently ... And he said 'how dare you, you tell me l'm a valued person, I'm entitled to my feelings.' But we're saying 'yes, but that doesn't entitle you to go off on one with other people.' So I think he's still a bit confused. Where, ok you're a valued person but that doesn't say you can do anything you want to do. (Jackie.)

Some survivors described the kudos that their (ex-) partner obtained, because they attended a perpetrator programme, at court; while they, the abuse survivor, could see no related improvements in behaviour, for example:

Interviewee: The only reason he did it was to get back with his kids.

Interviewer: And did it help him get his kids back, did the court look favourably upon it?

Yes. (Janet.)

He was told that I couldn't be with him because of the domestic violence so he was doing a course to show that he was safe to be around children. (Jessie.)

I think there is a difference between those who want a genuine change and those who are taking advantage of the course. And I think when they are 
really bad, and the problems are really deep-rooted, the family has to be asked and given priority. (Gerri.)

There were also further insights into how some (ex-) partners took hope and security from the fact that their partner had engaged with treatment, in advance of any actual improvements in behaviour:

Oh, he is actually admitting, because he is putting himself forward for this course. It gave me hope for the first time in years. For the first time in maybe 10 years. I became isolated by my friends and family during the course when people saw that I was actually supporting this. They stepped back from me, they were just thinking that I was nuts. The course give me another reason to stay in there, when in my mind I wanted to get out. I was at loggerheads with myself, I said to myself, "I will give this a go, if I don't well at least then I can say I tried." (Tessa.)

These insights, summarised in Table 1, into how perpetrator programmes can affect relationship dynamics give us pause to consider, are programme evaluations designed to detect these effects?

Insert Table 1.

\section{Discussion}

These study findings encourage us to pause and consider what it is that we are hoping to achieve through IPV perpetrator programmes. Pioneers of perpetrator programme development, Pence and Paymar (1993), saw such programmes as just one part of an integrated community response to the problem. Shepard and Pence (1999) were quite clear about the limitations of the IPV perpetrator programmes they were involved in. They highlighted how appropriate responses from the judiciary and law enforcement are central to the protection of IPV survivors. Current study findings bring us back to Pence and Paymar's primary concern: the safety of IPV survivors.

Survivors interviewed in this study did not talk about incidents of physical violence as if these were their first concern. Survivors focused on the situation they were in, or had been in, and the effects on their own and their children's well-being. They spoke of hopes or despairs for the future, and the safety of their children. These findings support calls for more holistic measures of change, as experienced by survivors (Featherstone \& Fraser, 2012; Goldman \& Du Mont, 2001); and, more specifically, calls to consider survivors feelings of safety, self-efficacy and social support when measuring the efficacy of perpetrator programmes (O'Doherty et al., 2014; Respect, 2012; Wojnicka et al., 2016).

Sporadically, findings pertaining to feelings of safety do surface in published evaluations of perpetrator programmes. Gondolf (1999) and R. P. Dobash et al. (1999) measured feelings of safety but presented perpetrator programme completion and reassault statistics as principal measures. These are clearly more perpetrator centric measures and it is not difficult to conceive of perpetrators avoiding reconviction while continuing to abuse (Gondolf, 2004). Two, more recent, evaluations (Kelly \& Westmarland, 2015; McConnell, Barnard, Holdsworth, \& Taylor, 2014) have placed survivor well-being, and feelings of safety centre-stage. But, as outlined in the 
introduction, other recent evaluations have used recidivism data, and ignored more holistic measures of programme efficacy.

A few of the survivors interviewed in this study experienced significant change in their partners' behaviour. A few saw some change but were unsure of the nature of it or were suspect of its sustainability. A majority longed for a safe separation from their violent partner, and the question arises: did the perpetrator programme help facilitate this? All three of the perpetrator programmes, involved in this study, address the topic of respecting partners' wishes. These programmes endeavour to help perpetrators understand their partners' right to self-determination, including their right to separate without fear of repercussions. However, survivors did not appear to experience the fruits of these endeavours.

The current study provides explicit, referenceable evidence in support of survivorcentric outcome measures. If we accept that survivors' and children's safety is where we are trying to get to, then we should also accept that perpetrator programmes are just one, of several ways, we can try and bring this about. On the basis of current study findings, we are obliged to highlight the possibility that, for more families than is generally acknowledged, perpetrator programmes are not the best way forward. Evidence from the British crime survey, provided by Walby, Allen, and Britain (2004), showed that $88 \%$ of partner-violence survivors stated that the violence in their relationship ended because the relationship ended (not because the perpetrator changed). A US based longitudinal study of 348 men arrested for partner-violence related offences (Pico-Alfonso, Echeburua, \& Martinez, 2008) showed that three quarters of them reoffended, and an international review of 31 studies of sanctions concluded that the various sanctions applied to this population have no effect (Maxwell \& Garner, 2012). Perpetrator change is possible, but by no means the norm, and perhaps better conceptualised as an elusive goal which is extremely difficult to bring about in a way that will make surviving families feel safe. If we accept that interventions to change perpetrators are not always the most expeditious route to family safety, or indeed a credible goal for many abused families, it follows that where they are deployed they must be evaluated more rigorously, against more relevant measures.

We might also consider focusing resources on safe separation, rather than perpetrator change, in light of the insights provided here, into how some survivors can be placed in more difficult positions by perpetrator programmes. Survivors in this study were aware of the kudos their partner obtained at court, from their engagement with a programme. A few survivors pointed out how the programme offered them a reason to stay in a relationship that they should have got out of. These, and other potential problems with perpetrator programmes, have been discussed previously (AugustaScott \& Dankwort, 2002; Buttell, 1999; Eckhardt et al., 2013; Feazell, Mayers, \& Deschner, 1984; Feder et al., 2008; Gondolf, 1987, 2004; Hart \& Klein, 2013; Jory, Anderson, \& Greer, 1997; Labriola, Rempel, \& Davis, 2005; Smedslund et al., 2011). The need for a wider perspective on programme efficacy which captures possible negative outcomes for survivors, is therefore key. Measures such as survivor and children well-being in the longer term would achieve this.

We would join with Morrison et al. (2018) in encouraging policy makers and perpetrator programme stakeholders to revisit the original Duluth philosophy in Pence and Paymar (1993). Pence and Paymar saw their work with perpetrators as just one part of a 
community response to IPV; a part which was to be entirely integrated with a strong legal mandate to forcibly protect survivors and their families through appropriate sanctions such as protection orders and custodial sentences. The facility to create space for surviving families, and to facilitate safe separations from abusive partners would appear more tangible in such a scenario. Gondolf (2002) describes an example of a properly integrated programme from Pittsburgh, which performed particularly well in his multi-site efficacy study. This was a three-month, pre-trial programme, with swift court involvement and regular court review: "In sum, the men were held more quickly and decisively accountable for their behaviour" (p.203).

Current study findings also prompt consideration of what kind of modifications might come about, if survivor feelings of safety became a universal primary objective, and perpetrator programmes were evaluated more rigorously and consistently to this end. We would suggest that two aspects or perpetrator programmes would come under focus: the screening and assignment of perpetrators to appropriate intervention; and the integration of perpetrator work with legal sanctions such as protection orders.

In relation to the screening and assignment of perpetrators, if survivor safety becomes a more explicit focus then we would envisage more time being spent with surviving families to gauge the level of vulnerability therein. A few survivors interviewed in this study were in a position to assimilate and act upon any detrimental changes in their partners' behaviour. They felt that they could separate from their partner if they wanted or needed to. In contradistinction, some survivors, were in their relationship because they feared the repercussions from their partner if they tried to end the relationship. Clearly these abuse survivors had been largely disempowered. It follows that they were not in a good position to feed back any problem effects of the programme to their programme outreach worker, nor where they in a position to separate from their abusive partner; Dichter and Gelles (2012) present a similar discussion. We would suggest that abused partners' level of empowerment is used to demarcate between perpetrators that can be referred to a perpetrator programme and perpetrators who cannot.

The insight provided by Justine, in current study findings, underlines the need for a strong legal mandate for intervention, and appropriate custodial sentences. In this instance the police had taken responsibility for bringing charges against Justine's abusive partner, even though she had withdrawn her statement from the police's evidence. Other survivors described difficulties, and missed opportunities, for the police and the judiciary to intervene more decisively.

In the scenario described by Justine she was divested of her responsibility to police her partner's behaviour, the police did it. They took action against her violent partner without her support. This scenario calls to mind Westmarland and Kelly's (2012, p. 9) conceptualisation of "space for action"; and brings us to the debate about whether or not it is the state's place to step in, and take action, regardless of victims' wishes. Commentators have voiced reservations about no-drop prosecution policies (Hare, 2006; Nichols, 2014). It has been argued that, when a prosecution system intervenes without the support of victims, victims are being further disempowered. Spanish survivors interviewed by Cubells and Calsamiglia (2018) offer insights into feelings of lost agency. Gover, Welton-Mitchell, Belknap, and Deprince (2013) report how survivors do not report additional incidents of violence to the police, most commonly, 
because they feel the incidents are not serious enough. Sleath and Smith (2017) analysed 524 prosecution cases to find that being from a deprived area, and having a higher risk assessment score were key predictors of victims' withdrawing support for prosecution. These, and other studies, remind us that abuse survivors are in very difficult positions, and may not be best placed to leverage the judicial system to their own benefit.

We would point out that unwieldy, ineffectual, judicial systems which offer little reward for survivors, in the end, (Childress \& Hanusa, 2018; Cubells \& Calsamiglia, 2018) are a more convincing argument not to press ahead with more judicial interventions. However, where a judicial system responds robustly to IPV (Lewis, 2004, describes a number of examples) then current study findings suggest we should consider this route to survivor safety with more frequency. We would add, that concerns which dilute the application of no-drop prosecution policies might be diminished through the provision of effective survivor support, through the judicial process, for which there is resounding call to arms (O'Neal, 2017; Smith Stover, 2012; Taylor-Dunn, 2016).

To reinforce the argument for more proactive judicial interventions we would also point out that when a public prosecution agency decides not to pursue sanctions against an IPV perpetrator, in deferment to a victim's wishes (under duress or otherwise) they are relegating their role in public protection. When a custodial sentence, or a 'no contact' order is not imposed, at the victim's volition, the victim's children, extended family, friends and neighbours must continue to live alongside the perpetrator.

Most present-day societies are ostensibly committed to ridding themselves of violence in all its forms; and taking violence out of society works. Reducing corporal punishment has had a positive impact on the level of violence in society (Fréchette, Zoratti, \& Romano, 2015). Consider also, how IPV can be handed forwarded from generation to generation (Stith et al., 2000). In this context, decisions not to bring the full weight of criminal sanction for an assault, or a protection order violation, to IPV situations suggests a concessionary approach to perpetrators, and a dis-service to the immediate community and more generally: society as a whole.

Finally, programme providers should take note of the state of flux which can emerge, for surviving families, following perpetrators' completion of a perpetrator programme. Current study findings suggest that survivors struggled to trust change, they struggled to gauge the quality of change, and to know what type of change they would, or should, be happy with. When talking about their present or past abusive situations there was a particular inability to quantify abusive behaviour. The evidence provided here helps disband the notion of perpetrator change as a cause-and-effect type event. Previous qualitative researchers have also raised this point. "Specifically, the process of change was described as a cyclical series of advances and setbacks" (Stefanakis, 2000, p. 2). Gondolf (2000) highlighted the challenge perpetrators have in turning new learning and beliefs into new behaviour: "it is not acceptable I know but it doesn't seem to make any bloody difference to my behaviour" (a perpetrator interviewed by Gondolf). Similar insights are offered by R. E. Dobash et al. (2000), Bonham and Vetere (2012) and Gregory and Erez (2002). Programme evaluations which focus on abuse trajectories over long post-programme time-frames would seem prudent in this scenario, using measures of family well-being and safety.

\section{Limitations}


In assimilating the findings reported here readers should be aware that this study did not include children's perspective on change in their abusive parent, this is a shortfall given that children's well-being is of central importance in perpetrator intervention (Katz, 2016). Findings should also be interpreted with the participant sampling frame in mind. Survivors who were thought to be in a comparatively safe position were given the opportunity to take part. While many study participants were able to talk about very difficult circumstances during the interview, it could be argued that they did not adequately represent survivors who were in very dangerous circumstances.

The sample included study participants from both the Republic of Ireland and Northern Ireland, interviews were conducted in 10 of the 32 counties across the Island of Ireland, and drew upon three perpetrator programmes. However, at least three other perpetrator programmes were in operation at the time of data collection. The findings presented here may not be representative of survivors' perspectives on other perpetrator programmes in Ireland, and the perspectives of Irish survivors may not be generalisable to other regions where perpetrator programmes are used. In relation to study participant characteristics, the study sample was a reasonable reflection of Irish socio-economic groups. However, Ireland's population has a growing number of ethnic groups which are arguably not adequately reflected in the study sample. Just two participants were not Irish born and of a different ethnicity.

Finally, qualitative study findings are constructed by researchers based on their interpretations of study participant utterances. Mindful of the potential for researcher bias this study incorporated secondary, independent, data analysis as a check on the legitimacy of the data categories assigned to the data. Four interviewees' data were subjected to this additional analysis. The rigour in data analysis could have been further improved by subjecting all of the data gathered to secondary analysis.

\section{Conclusion}

Families living with IPV can either separate from the abusive parent, or the abusive parent can change their behaviour. Acknowledging that there may be some overlap between these scenarios, we suggest that these are the two principal routes to safety, for abused families. In this scenario there is an obvious, and logical, role for IPV perpetrator programmes. These programmes can help perpetrators change their behaviour. They do not always work, but, as described by a few of the survivors who participated in this study, perpetrator programmes can be a transformative experience. There would appear to be a logical rationale for our nigh on 50-year commitment to the development and delivery of IPV perpetrator programmes. However, when we are in the business of funding, developing, delivering, or evaluating perpetrator programmes it is easy to become locked into a paradigm of perpetrator change. It is easy to lose sight of the fact that there is another route to family safety: safe separation.

This study was conducted using a grounded theory methodology. Researchers are encouraged to generate new theory using this method, theory which is grounded in the data gathered (Glaser \& Strauss, 1967). Arguably, the substance within the data categories described here (empowerment, safety, sustainable change, children and detrimental changes) could be moulded into a statement of theory: families' feelings of safety are the most valid measure of perpetrator programme success. Adopting 
families' feelings of safety as the primary outcome of interest in this field, would change the shape of our response to IPV. It would bring survivors' right to separate safely from their violent partner sharply into focus, and perpetrator programmes would be used more appropriately.

\section{References}

Akoensi, T. D., Koehler, J. A., Lösel, F., \& Humphreys, D. K. (2012). Domestic violence perpetrator programs in Europe, Part II: a systematic review of the state of evidence. International Journal of Offender Therapy and Comparative Criminology, 57 (10), 1206-1225. doi:10.1177/0306624X12468110

Alderson, S., Westmarland, N., \& Kelly, L. (2013). The need for accountability to, and support for, children of men on domestic violence perpetrator programmes. Child Abuse Review, 22(3), 182-193.

Augusta-Scott, T., \& Dankwort, J. (2002). Partner abuse group intervention: lessons from education and narrative therapy approaches. Journal of Interpersonal Violence, 17(7), 783-805. Retrieved from http://search.proquest.com/docview/57518068?accountid=14775.

Babcock, J. C., Green, C. E., \& Robie, C. (2004). Does batterers' treatment work? A meta-analytic review of domestic violence treatment. Clinical Psychology Review, 23(8), 1023-1053.

Bloomfield, S., \& Dixon, L. (2015). An outcome evaluation of the Integrated Domestic Abuse Programme (IDAP) and Community Domestic Violence Programme (CDVP). Retrieved from

UK: https://assets.publishing.service.gov.uk/government/uploads/system/uploads/attach ment data/file/449008/outcome-evaluation-idap-cdvp.pdf

Bonham, E., \& Vetere, A. L. (2012). A qualitative study using a systemic perspective exploring the remediation of abusive interactions in intimate heterosexual couples. Journal of Interpersonal Violence, 27(5), 916-929. Retrieved from http://ovidsp.ovid.com/athens/ovidweb.cgi?T=JS\&CSC=Y\&NEWS=N\&PAGE=fulltext \&D=emed10\&AN $=22203613$

http://openurl.ac.uk/athens:uls/Resolver/?genre=article\&sid=OVID:emed10\&issn= $\underline{0886-}$

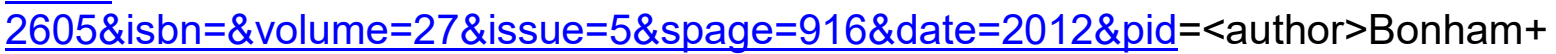
E.

Buttell, F. P. (1999). Level of Moral Reasoning Among African-American and Caucasian Domestic Violence Offenders Prior to Targeted Professional Intervention. Retrieved from United States: http://search.proquest.com/docview/9861285?accountid=14775

Childress, S., \& Hanusa, D. J. J. o. F. V. (2018). "All the System is Simply a Soap Bubble": Legal Help-Seeking for Domestic Violence Among Women in Kyrgyzstan. 33(2), 147-160.

Clarke, A., \& Wydall, S. (2013). 'Making Safe': a coordinated community response to empowering victims and tackling perpetrators of domestic violence. Social Policy and Society, 12(3), 393-406.

Coulthard, P., Yong, S. L., Adamson, L., Warburton, A., Worthington, H. V., Esposito, M., \& Sharif, M. O. (2010). Domestic violence screening and intervention programmes for adults with dental or facial injury. Cochrane Database Syst Rev, 8. Retrieved from https://www.cochranelibrary.com/cdsr/doi/10.1002/14651858.CD004486.pub2/abstra ct. doi:10.1002/14651858.CD004486.pub2 
Cubells, J., \& Calsamiglia, A. J. C. c. (2018). Do We See Victims' Agency? Criminal Justice and Gender Violence in Spain. 26(1), 107-127.

Dichter, M. E., \& Gelles, R. J. (2012). Women's Perceptions of Safety and Risk Following Police Intervention for Intimate Partner Violence. Violence against women, 18(1), 44-63.

Dobash, R. E., Dobash, R. P., Cavanagh, K., \& Lewis, R. (2000). Changing violent men: Sage London.

Dobash, R. P., Dobash, R. E., Cavanagh, K., \& Lewis, R. (1999). A research evaluation of British programmes for violent men. Journal of Social Policy, 28(2), 205233. Retrieved from https://www.cambridge.org/core/journals/journal-of-socialpolicy/article/research-evaluation-of-british-programmes-for-violentmen/E921118F14303B91EBD22EDC9495D638. doi:10.1177/1077801207311859

Dunford, F. W. (2000). The San Diego Navy Experiment: An assessment of interventions for men who assault their wives. Journal of Consulting and Clinical Psychology, 68(3), 468.

Dutton, D. G., \& Corvo, K. (2007). The Duluth model: A data-impervious paradigm and a failed strategy. Aggression and violent behavior, 12(6), 658-667. doi:10.1016/j.avb.2007.03.002

Easton, C. J., Mandel, D. L., Hunkele, K. A., Nich, C., Rounsaville, B. J., \& Carroll, K. M. (2007). A Cognitive Behavioral Therapy for Alcohol-Dependent Domestic Violence Offenders: An Integrated Substance Abuse-Domestic Violence Treatment Approach (SADV). The American Journal on Addictions, 16(1), 24-31.

Eckhardt, C. I., Murphy, C. M., Whitaker, D. J., Sprunger, J., Dykstra, R., \& Woodard, K. (2013). The effectiveness of intervention programs for perpetrators and victims of intimate partner violence. Partner Abuse, 4(2), 196-231.

Featherstone, B., \& Fraser, C. (2012). Working with fathers around domestic violence: Contemporary debates. Child Abuse Review, 21(4), 255-263.

Feazell, C. S., Mayers, R. S., \& Deschner, J. J. F. R. (1984). Services for men who batter: Implications for programs and policies. 217-223.

Feder, L., \& Dugan, L. (2002). A test of the efficacy of court.mandated counseling for domestic violence offenders: The Boward Experiment. Justice Quarterly, 19(2), 343-375.

Retrieved

from

http://ovidsp.ovid.com/athens/ovidweb.cgi?T=JS\&CSC=Y\&NEWS=N\&PAGE=fulltext $\& \mathrm{D}=\mathrm{cctr} \& \mathrm{AN}=\mathrm{CN}-00592820$

http://openurl.ac.uk/athens:uls/Resolver/?genre=article\&sid=OVID:cctr\&issn=0741 8825\&isbn=\&volume=19\&issue=2\&spage $=343 \&$ date $=2002 \&$ pid $=<$ author $>$ Feder $+\mathrm{L} \%$ 2C+Dugan+L.

Feder, L., Wilson, D. B., \& Austin, S. (2008). Court-mandated interventions for individuals convicted of domestic violence. Campbell Systematic Reviews, 12. doi:10.4073/csr.2008.12

Ferrer-Perez, V. A., \& Bosch-Fiol, E. (2016). Batterer Intervention Programs in Spain An Analysis of Their Effectiveness. International Journal of Offender Therapy and Comparative Criminology, 0306624X16672455. doi:0306624X16672455

Fontes, L. A. (2004). Ethics in violence against women research: The sensitive, the dangerous, and the overlooked. Ethics \& Behavior, 14(2), 141-174. doi:10.1207/s15327019eb1402_4

Fréchette, S., Zoratti, M., \& Romano, E. (2015). What is the link between corporal punishment and child physical abuse? Journal of Family Violence, 30(2), 135-148. 
Fruzzetti, A. E., \& Levensky, E. R. (2000). Dialectical behavior therapy for domestic violence: Rationale and procedures. Cognitive and Behavioral Practice, 7(4), 435-447.

Gerlock, A. A. (2001). Relationship Mutuality: Why Is It Important in Batterers' Rehabilitation? Journal of Interpersonal Violence, 16(8), 768-768-783. Retrieved from http://search.proquest.com/docview/61525646?accountid=14775

http://openurl.ac.uk/athens:uls/?genre=article\&issn=0886-

2605\&volume=16\&issue=8\&title=Journal\%20of\%20Interpersonal $\% 20$ Violence \&spag $\mathrm{e}=768 \&$ date $=2001-08-$

01\&atitle=Relationship $\% 20$ Mutuality: $\% 20$ Why $\% 20$ Is $\% 20$ It $\% 20$ Important $\% 20 \mathrm{in} \% 20 \mathrm{~B}$ atterers'\%20Rehabilitation?\&aulast=Gerlock, \%20April\%20A.

Glaser, B. G., \& Strauss, A. L. (1967). The discovery of grounded theory: Strategies for qualitative research: Aldine de Gruyter.

Goldman, J., \& Du Mont, J. (2001). Moving forward in batterer program evaluation: posing a qualitative, woman-centered approach. Evaluation and Program Planning 24 (2001) 297 $\pm 305,24,297$ - 305.

Gondolf, E. W. (1987). Evaluating programs for men who batter: Problems and prospects. Journal of Family Violence, 2(1), 95-108.

Gondolf, E. W. (1999). A comparison of four batterer intervention systems: Do court referral, program length, and services matter? Journal of Interpersonal Violence, 14(1), 41-61.

Gondolf, E. W. (2000). How batterer program participants avoid reassault. Violence against women, 6(11), 1204-1222. Retrieved from http://ovidsp.ovid.com/athens/ovidweb.cgi?T=JS\&CSC=Y\&NEWS=N\&PAGE=fulltext \&D=psyc $3 \& A N=2000-16110-002$

http://openurl.ac.uk/athens:uls/Resolver/?genre=article\&sid=OVID:psyc3\&issn=10 $77-$

$\underline{801}$ \& \&isbn $=$ \&volume $=6$ \&issue $=11 \&$ spage $=1204 \&$ date $=2000 \&$ pid $=<$ author $>$ Gondolf + Edward+W.

Gondolf, E. W. (2002). Service barriers for battered women with male partners in batterer programs. Journal of Interpersonal Violence, 17(2), 217-227. Retrieved from http://search.proquest.com/docview/57524962?accountid=14775.

doi:10.1177/0886260502017002007

Gondolf, E. W. (2004). Evaluating batterer counseling programs: A difficult task showing some effects and implications. Aggression and violent behavior, 9(6), 605631. doi:10.1016/j.avb.2003.06.001

Gondolf, E. W. (2007). Theoretical and research support for the Duluth Model: A reply to Dutton and Corvo. Aggression and violent behavior, 12(6), 644-657.

Gondolf, E. W. (2012). The Future of Batterer Programs Reassessing EvidenceBased Practice. Indiana: Northeastern University Press.

Gover, A. R., Welton-Mitchell, C., Belknap, J., \& Deprince, A. P. (2013). When Abuse Happens Again: Women's Reasons for Not Reporting New Incidents of Intimate Partner Abuse to Law Enforcement. Women \& Criminal Justice, 23(2), 99-120. Retrieved from http://search.ebscohost.com/login.aspx?direct=true\&db=cja\&AN=86009523\&site=eh ost-live. doi:10.1080/08974454.2013.759069

Gregory, C., \& Erez, E. (2002). The effects of batterer intervention programs: the battered women's perspectives. Violence against women, 8(2), 206-232. Retrieved from http://search. proquest.com/docview/57534527? accountid=14775. 
Griffin, M. G., Resick, P. A., Waldrop, A. E., \& Mechanic, M. B. (2003). Participation in trauma research: Is there evidence of harm? Journal of Traumatic Stress, 16(3), 221-227.

Haggård, U., Freij, I., Danielsson, M., Wenander, D., \& Långström, N. (2015). Effectiveness of the IDAP Treatment Program for Male Perpetrators of Intimate Partner Violence A Controlled Study of Criminal Recidivism. Journal of Interpersonal Violence, 0886260515586377.

Hare, S. C. (2006). What do battered women want? Victims' opinions on prosecution. Violence and Victims, 21(5), 611-628. Retrieved from http://ovidsp.ovid.com/athens/ovidweb.cgi?T=JS\&CSC=Y\&NEWS=N\&PAGE=fulltext \&D=med5\&AN $=17022353$

http://openurl.ac.uk/athens:uls/Resolver/?genre=article\&sid=OVID:med5\&issn=08 86-

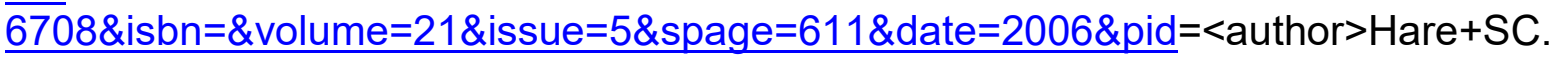

Hart, B. J., \& Klein, A. R. (2013). Practical Implications of Current Intimate Partner Violence Research for Victim Advocates and Service Providers. 260. Retrieved from https://search.proquest.com/docview/1499062399?accountid=14775

http://openurl.ac.uk/athens:uls/?genre=article\&issn=\&volume=\&issue=\&title=\&spa ge=\&date=2013-01-

01\&atitle=Practical+Implications+of+Current+Intimate+Partner+Violence+Research+ for+Victim+Advocates+and+Service+Providers\&aulast=Hart\%2C+Barbara+J. \%3BKI ein $\% 2 C+$ Andrew+R.\&id=doi:

https://www.ncjrs.gov/pdffiles1/nij/grants/244348.pdf.

Hasisi, B., Shoham, E., Weisburd, D., Haviv, N., \& Zelig, A. (2016). The "care package," prison domestic violence programs and recidivism: a quasi-experimental study. Journal of Experimental Criminology, 12(4), 563-586.

Jennings, J. L. (1987). History and issues in the treatment of battering men: A case for unstructured group therapy. Journal of Family Violence, 2(3), 193-213. Retrieved from

http://ovidsp.ovid.com/athens/ovidweb.cgi?T=JS\&CSC=Y\&NEWS=N\&PAGE=fulltext \&D=psyc3\&AN=1988-36526-001

http://openurl.ac.uk/athens:uls/Resolver/?genre=article\&sid=OVID:psyc3\&issn=08 85-

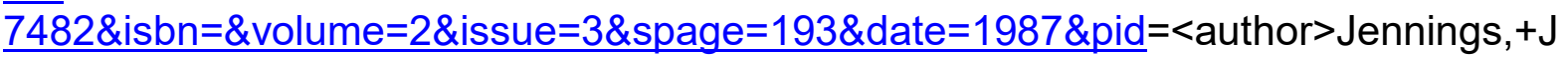
erry+L.

Jory, B., Anderson, D., \& Greer, C. (1997). Intimate justice: confronting issues of accountability, respect, and freedom in treatment for abuse and violence. Journal of Marital and Family Therapy, 23(4), 399-419. Retrieved from http://ovidsp.ovid.com/athens/ovidweb.cgi?T=JS\&CSC=Y\&NEWS=N\&PAGE=fulltext \&D=emed4\&AN=9338859

http://openurl.ac.uk/athens:uls/Resolver/?genre=article\&sid=OVID:emed4\&issn=0 194-

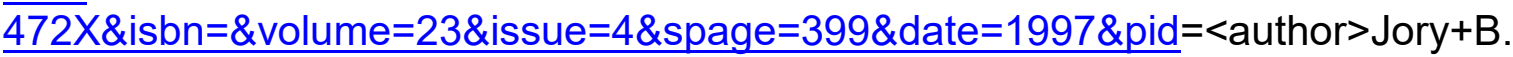

Katz, E. (2016). Beyond the physical incident model: how children living with domestic violence are harmed by and resist regimes of coercive control. Child Abuse Review, 25(1), 46-59.

Kelly, L., \& Westmarland, N. (2015). Domestic Violence Perpetrator Programmes: Steps Towards Change. Project Mirabal Final Report. Retrieved from London and Durham: 
Labriola, M., Rempel, M., \& Davis, R. C. (2005). Testing the effectiveness of batterer programs and judicial monitoring. Results from a Randomized Trial at the Bronx Misdemeanor Domestic Violence Court. New York, NY: Center for Court Innovations.

Lewis, R. (2004). Making justice work: effective legal interventions for domestic violence. British Journal of Criminology, 44(2), 204-224. Retrieved from http://search.proquest.com/docview/57193956?accountid=14775.

Maxwell, C. D., Davis, R. C., \& Taylor, B. G. (2010). The impact of length of domestic violence treatment on the patterns of subsequent intimate partner violence. Journal of Experimental Criminology, 6(4), 475-497.

McCallin, A. M. (2003). Designing a grounded theory study: Some practicalities. Nursing in Critical Care, 8(5), 203-208.

McConnell, N., Barnard, M., Holdsworth, T., \& Taylor, J. (2014). Caring Dads SAFER CHILDREN Interim evaluation report. Retrieved from

McGinn AH, McColgan M \& Taylor BJ (2020) Male IPV perpetrators' perspectives on intervention and change: a systematic synthesis of qualitative studies. Trauma, Violence \& Abuse, 21(1), 97-112. https://doi.10.1177/1524838017742167

McGinn AH, Taylor BJ, McColgan M \& Lagdon S (2016) Survivor perspectives on IPV perpetrator interventions: systematic narrative review. Trauma, Violence \& Abuse, 17(3), 239-255. https://doi.10.1177/1524838015584358 [published online 11 May 2015] [A64]

Morrison, P. K., Hawker, L., Cluss, P. A., Miller, E., Fleming, R., Bicehouse, T., . . . Chang, J. C. (2018). The challenges of working with men who perpetrate partner violence: perspectives and observations of experts who work with batterer intervention programs. Journal of Interpersonal Violence, 0886260518778258.

Nichols, A. J. (2014). No-Drop Prosecution in Domestic Violence Cases: SurvivorDefined and Social Change Approaches to Victim Advocacy. Journal of Interpersonal Violence, 29(11), 2114. Retrieved from https://search.proquest.com/docview/1534525767?accountid=14775

http://openurl.ac.uk/athens:uls/?genre=article\&issn=08862605\&volume=29\&issue $=11 \&$ title=Journal+of+Interpersonal+Violence\&spage=2114\&date=2014-07-

01\&atitle=No-Drop+Prosecution+in+Domestic+Violence+Cases\%3A+SurvivorDefined+and+Social+Change+Approaches+to+Victim+Advocacy\&aulast=Nichols $\% 2$ C+Andrea+J\&id=doi:.

O'Doherty, L. J., MacMillan, H., Feder, G., Taft, A., Taket, A., \& Hegarty, K. (2014). Selecting outcomes for intimate partner violence intervention trials: overview and recommendations. Aggression and violent behavior, 19(6), 663-672.

O'Neal, E. N. J. J. Q. (2017). Victim cooperation in intimate partner sexual assault cases: A mixed methods examination. 34(6), 1014-1043.

Office for National Statistics. (2015). Focus on: Violent Crime and Sexual Offences, 2013/14 - Appendix Tables. Retrieved from http://www.ons.gov.uk/ons/rel/crimestats/crime-statistics/focus-on-violent-crime-and-sexual-offences--2013-14/rpt-aboutthis-release.html

Pence, E. (1983). The Duluth domestic abuse intervention project. Hamline L. Rev., 6, 247.

Pence, E., \& Paymar, M. (1993). Education groups for men who batter: The Duluth model: Springer Publishing Company.

Respect. (2012). The Respect Accreditation Standard: 2nd Edition July 2012. In. London: Respect. 
Rosenbaum, A., Gearan, P., \& Ondovic, C. (2001). Completion and recidivism among court-and self-referred batterers in a psychoeducational group treatment program: Implications for intervention and public policy. Journal of agression, malteatment and trauma, 5(2), 199-220.

Rubin, A. (2000). Standards for rigor in qualitative inquiry. Research on Social Work Practice, 10(2), 173-178.

Scerri, C. S., Abela, A., \& Vetere, A. (2012). Ethical dilemmas of a clinician/researcher interviewing women who have grown up in a family where there was domestic violence. International journal of qualitative methods, 11(2), 102-131. Retrieved from http://search.proquest.com/docview/1124748642?accountid=14775.

Shepard, M., \& Pence, E. (1999). Coordinating Community Responses to Domestic Violence: Lessons from Duluth and Beyond. Thousand Oaks, California: Sage.

Silvergleid, C. S., \& Mankowski, E. S. (2006). How batterer intervention programs work: participant and facilitator accounts of processes of change. Journal of Interpersonal Violence, 21(1), 139-159. Retrieved from http://search.ebscohost.com/login.aspx?direct=true\&db=jlh\&AN=2009096344\&site=e host-live.

Sleath, E., \& Smith, L. (2017). Understanding the factors that predict victim retraction in police reported allegations of intimate partner violence. Psychology of Violence, 7(1), 140 - 155.

Smedslund, G., Dalsbø, T. K., Steiro, A. K., Winsvold, A., \& Clench-Aas, J. (2011). Cognitive behavioural therapy for men who physically abuse their female. Cochrane Systematic Reviews, 1.

Smith Stover, C. (2012). Police-Advocacy Partnerships in Response to Domestic Violence. Journal of Police Crisis Negotiations, 12(2), 183-198. Retrieved from https://search.proquest.com/docview/1550997001?accountid=14775

http://openurl.ac.uk/athens:uls/?genre=article\&issn=15332586\&volume=12\&issue $=2 \&$ title=Journal+of+Police+Crisis+Negotiations\&spage=183\&date=2012-01-

01\&atitle=Police-

Advocacy+Partnerships+in+Response+to+Domestic+Violence\&aulast=Smith+Stover \%2C+Carla\&id=doi:10.1080\%2F15332586.2012.717031.

doi:org/10.1080/15332586.2012.717031

Stefanakis, H. (2000). Desistence from violence: Men's stories of identity transformation. (PhD), University of Guelph,

Stith, S. M., Rosen, K. H., Middleton, K. A., Busch, A. L., Lundeberg, K., \& Carlton, R. P. (2000). The Intergenerational Transmission of Spouse Abuse: A Meta-Analysis. Journal of Marriage and family, 62(3), 640-654.

Straus, M. A., Hamby, S. L., Boney-McCoy, S., \& Sugarman, D. B. (1996). The revised Conflict Tactics Scales (CTS2) development and preliminary psychometric data. Journal of Family Issues, 17(3), 283-316.

Taylor-Dunn, H. (2016). The impact of victim advocacy on the prosecution of domestic violence offences: Lessons from a Realistic Evaluation. Criminology \& Criminal Justice, 16(1), $21 . \quad$ Retrieved from https://search.proquest.com/docview/1762016577? accountid=14775

http://openurl.ac.uk/athens:uls/?genre=article\&issn=17488958\&volume=16\&issue $=1 \&$ title $=$ Criminology $+\% 26+$ Criminal + Justice $+\% 3 A+C$ CJ\&spage $=21 \&$ date $=2016-02-$ 01\&atitle=The+impact+of+victim+advocacy+on+the+prosecution+of+domestic+viole nce+offences \%3A+Lessons+from+a+Realistic+Evaluation\&aulast=TaylorDunn\%2C+Holly\&id=doi:. 
Taylor, B. G., Davis, R. C., \& Maxwell, C. D. (2001). The effects of a group batterer treatment program: A randomized experiment in Brooklyn. Justice Quarterly, 18(1), 171-201.

Taylor, B. J., \& Donnelly, M. (2006). Professional perspectives on decision making about the long-term care of older people. British Journal of Social Work, 36(5), 807826.

Valentine, K., \& Breckenridge, J. (2016). Responses to family and domestic violence: supporting women? Griffith Law Review, 25(1), 30-44.

Westmarland, N., \& Kelly, L. (2012). Why Extending Measurements of 'Success' in Domestic Violence Perpetrator Programmes Matters for Social Work. British Journal of Social Work, 43(6), 1092-1110.

Wojnicka, K., Scambor, C., \& Kraus, H. (2016). New pathways in the evaluation of programmes for men who perpetrate violence against their female partners. Evaluation and Program Planning, 57, 39-47.

Zarling, A., Bannon, S., \& Berta, M. (2017). Evaluation of Acceptance and Commitment Therapy for Domestic Violence Offenders. Psychology of Violence, Advance online publication. Retrieved from http://dx.doi.org/10.1037/vio0000097

\section{Tables}

Table 1

\begin{tabular}{|c|c|}
\hline Empowerment & $\begin{array}{l}\text { - Perpetrator programmes can help survivors feel more } \\
\text { empowered as they validate survivors as survivors } \\
\text { - Survivors valued the insights about how or why their partner } \\
\text { was violent, from their programme outreach worker, and their } \\
\text { partner } \\
\text { - Survivors felt supported. Some described elevating their ideas } \\
\text { about what they wanted from their relationship. }\end{array}$ \\
\hline Safety & $\begin{array}{l}\text { - It is likely that abuse survivors will always maintain some level } \\
\text { of fear. } \\
\text { - A safe separation, free from fear of repercussion, was a priority } \\
\text { for a seven of the study participants. } \\
\text { - Incarceration of a violent partner can provide survivors with a } \\
\text { period of respite }\end{array}$ \\
\hline $\begin{array}{l}\text { Sustainable } \\
\text { change }\end{array}$ & $\begin{array}{l}\text { - There is an important difference between changes in } \\
\text { perpetrator behaviour and changes in underlying beliefs. } \\
\text { - Survivors worried that their partners were making superficial } \\
\text { changes in response to intervention and worried about the } \\
\text { sustainability of these. }\end{array}$ \\
\hline Children & $\begin{array}{l}\text { - Survivors are concerned for their children. Some had seen } \\
\text { improvements in their partners' interactions with their children, } \\
\text { others had not seen any improvements. }\end{array}$ \\
\hline $\begin{array}{l}\text { Detrimental } \\
\text { changes }\end{array}$ & $\begin{array}{l}\text { - Perpetrators can use new learning from their programme in a } \\
\text { negative way. } \\
\text { - Perpetrators can use their engagement with a perpetrator } \\
\text { programme for kudos at court. } \\
\text { - Perpetrators' engagement with a perpetrator programme can } \\
\text { encourage survivors to maintain the relationship, without any } \\
\text { evidence of programme effect. }\end{array}$ \\
\hline
\end{tabular}


